\title{
Biomass and Defoliation Tolerance of 12 Populations of Pseudoroegneria spicata at Two Densities
}

\author{
Jayanti Ray Mukherjee, ${ }^{1}$ Thomas A. Jones, ${ }^{2}$ and Thomas A. Monaco ${ }^{3}$ \\ ${ }^{1}$ Graduate Program of the Department of Wildland Resources and Ecology Center, Utah State University, Logan, UT, USA; and ${ }^{2}$ Research Geneticist and \\ ${ }^{3}$ Research Ecologist, USDA-ARS Forage and Range Research Laboratory, Logan, UT, USA.
}

\begin{abstract}
Pseudoroegneria spicata (Pursh.) A. Löve is an important native grass of the rangelands of the Intermountain West, USA and is widely used in this region for restoration applications. High grazing preference, together with high grazing sensitivity, has reduced the abundance of this species, indicating the need for the development of grazing-tolerant plant materials. While a genotype may be defoliation tolerant at low density, e.g., in an experimental setting, an effective grazing-tolerant genotype must also display this trait at higher densities resembling those found in natural and restoration settings. We compared 12 restoration plant materials for response to spring-defoliation at high $\left(25\right.$ plants $\left.\cdot \mathrm{m}^{-2}\right)$ and low $\left(8\right.$ plants $\left.\cdot \mathrm{m}^{-2}\right)$ plant densities in a field experiment. Two consecutive years of spring-defoliation reduced shoot biomass $19 \%$ compared to the nonspring-defoliated control, and this reduction was similar for the two densities examined. Two populations, P-3 and Acc:238, were able to compensate for shoot biomass after $2 \mathrm{yr}$ of spring-defoliation, while the remaining 10 populations undercompensated, as is commonly reported for cool-season grasses in arid and semiarid regions. While the association between control and springdefoliated shoot biomass was marginally positive $\left(R^{2}=0.26 ; P<0.10\right)$, we found a stronger negative association $\left(R^{2}=0.36\right.$; $P<0.05)$ between spring-defoliation tolerance and control shoot-biomass production. This suggests a possible trade-off between growth and defoliation tolerance (calculated as percentage of control biomass) among populations. Of the four commercially available plant materials in our study, the more recent prevariety germplasm, P-7, exhibited higher control shoot biomass and higher spring-defoliation tolerance than the older cultivars, Whitmar and Goldar. Anatone germplasm was intermediate but not statistically different from these other plant materials for these two traits.
\end{abstract}

Key Words: bluebunch wheatgrass, grazing compensation, Intermountain West, root biomass, shoot biomass

\section{INTRODUCTION}

Historic uncontrolled grazing by livestock is one of the pivotal reasons for degradation of native-plant communities on the rangelands of the Intermountain West (Whisenant 1999). The native bunchgrasses in this region are grazing sensitive, which is probably due to low evolutionary grazing pressures from native herbivores prior to European settlement (Mack and Thompson 1982; Loreti et al. 2001). This lack of innate grazing tolerance heightens the importance of evaluating native plant materials for defoliation tolerance that are intended for use in this region. Psendoroegneria spicata (Pursh.) A. Löve is a $\mathrm{C}_{3}$, perennial Triticeae bunchgrass that serves as an important source of forage throughout the Intermountain West (Monsen et al. 2004). This species is regarded as being sensitive to grazing relative to other perennial grasses, such as the introduced Agropyron desertorum (Fisch. ex Link) Schult. (Caldwell et al. 1981), and the native Elymus wawawaiensis J. Carlson \& Barkworth (Jones and Nielson 1997). Thus, it is likely that historic overgrazing of the highly preferred and grazingsensitive $P$. spicata in the late 19 th and early 20 th centuries

Author contributions to this research were 60\% (Jayanti Ray Mukherjee), 30\% (Thomas A. Jones), and 10\% (Thomas A. Monaco).

Correspondence and current address: Jayanti Ray Mukherjee, Research Associate, School of Life Sciences, University of KwaZulu-Natal, Westville Campus, Private Bag: X54001, Durban - 4000, South Africa. Email: plants@scientist.com

Manuscript received 27 March 2013; manuscript accepted 19 July 2013.

(c) 2013 The Society for Range Management has led to a decline in its abundance (Jones and Nielson 1997; Adler et al. 2005).

Both theoretical and empirical studies have shown that plants have the ability to compensate for tissue lost to defoliation, as remaining tissues can perform more efficiently (McNaughton 1983; Del-Val and Crawley 2005). But in semiarid to arid rangelands, plants often fail to completely replace tissue lost to defoliation, and therefore remain undercompensated for above-ground biomass production (Trlica and Rittenhouse 1993). Moreover, the negative effect of defoliation may be inflated at high plant densities (Lee and Bazzaz 1980), which are common in nature. Under such circumstances, intraspecific competition, which limits resource availability, can greatly reduce yield per plant (Banyikwa 1988) as well as individual leaf biomass (Archer and Detling 1984). Thus, it is important to study the simultaneous effects of density and defoliation (Banyikwa 1988) in order to understand how these effects interact with one another. If density interacts with defoliation tolerance in some populations, the selection of populations for better defoliation tolerance becomes more complicated. A desirable defoliation-tolerant plant material would be one that maintains relatively high shoot biomass despite defoliation at high density.

On natural rangelands, where plants typically occur at higher densities than under typical experimental conditions, even mild defoliation can severely damage P. spicata. This grass may require 6 to 8 yr to completely recover once heavily grazed (Mueggler 1972, 1975), but in spite of its grazing sensitivity, $P$. spicata continues to be a preferred species for restoration 
applications in the Intermountain West (Monsen et al. 2004). Two released cultivars of P. spicata, Goldar and Whitmar, and two prevariety germplasms, Anatone and P-7, are currently commercially available. In restoration applications, seeding rates of native species range from 100 to 300 seeds $\cdot \mathrm{m}^{-2}$, although establishment success under natural rangeland conditions is on the order of about 10 seedlings $\cdot \mathrm{m}^{-2}$ (Whisenant 1999). Therefore, greater tolerance to defoliation at high densities where resources are limited should result in greater persistence under rangeland conditions (Sheley 2008).

Defoliated-to-control shoot-biomass ratio has been used to estimate defoliation tolerance (Jones and Nielson 1997). In this study, we compared four commercially available (previously named) and eight experimental populations of $P$. spicata for their response to spring-defoliation at two plant densities. Newly generated photosynthetic area is believed to be important for $P$. spicata's recovery from defoliation (Richards and Caldwell 1985; Busso et al. 2001), but recovery is compromised by prolonged investments in root growth, even after severe defoliation, at the expense of shoot growth (Caldwell et al. 1981). For this reason, we compared above- and below-ground biomass production for the 12 populations.

Being a defoliation-sensitive, cool-season perennial grass, we tested the null hypothesis that all P. spicata populations would compensate for regrowth after two consecutive years of defoliation treatment (Hypothesis 1). We also tested the null hypothesis that the undefoliated controls of the more recently released germplasms of $P$. spicata, i.e., Anatone (released in 2003) and P-7 (released in 2001), would be no more productive than those of the older released cultivars, i.e., Whitmar (released in 1946) and Goldar (released in 1989; Hypothesis 2). Plant ecophysiological studies have suggested that there is an evolutionary trade-off between genotypes' ability to grow and tolerate resource shortages (Chapin 1980; Grime 2001). Therefore, we tested the null hypothesis that the less-productive populations (as measured by the control treatment) would no better compensate for lost biomass (Hypothesis 3). Grazing-sensitive grasses like $P$. spicata are known to invest more in root biomass than grazing-tolerant grasses like A. desertorum (Caldwell et al. 1981). Hence, we tested the null hypothesis that populations tolerant of spring-defoliation would respond to defoliation by curtailing root biomass similarly to populations susceptible to spring-defoliation (Hypothesis 4).

\section{MATERIALS AND METHODS}

We used four commercially grown released populations (Goldar, Whitmar, Anatone, and P-7) and eight experimental populations (P-1, P-22, Acc:238, P-24, P-26, P-3, P-27t, and $\mathrm{P}-9 \mathrm{t})$ for this study. All populations are diploid $(2 n=14)$, except for two tetraploid $(2 n=28)$ populations, P- $27 \mathrm{t}$ and P$9 t$, so indicated by the "t $\mathrm{t}$ suffix (Table S1; available online at http://dx.doi.org/10.2111/REM-D-13-00049.s1). The 12 populations were included in the study because they are currently in use for restoration applications in the region (described as "released" above in this paragraph) or are being considered for such use (described as "experimental" above).
Seeds of these populations were germinated in plastic boxes in the laboratory. About $1 \mathrm{wk}$ after adding water, seedlings were transplanted into a 3:1 sand:peat moss mixture in opaque, round plastic cones $(20-\mathrm{cm}$ long $\times 5-\mathrm{cm}$ wide). Seedlings were reared in a greenhouse in Logan, Utah. After about $3 \mathrm{mo}$, on 18-19 May 2005, seedlings of the 12 populations were transplanted at two densities to the Utah State University Millville Farm near Logan. The soil was a Ricks gravelly loam (coarse-loamy over sandy or sandyskeletal, mixed, superactive, mesic Calcic Haploxerolls), typical of a semiarid sagebrush steppe site in the western foothills of the Wasatch Mountains of the eastern Great Basin, that had been cleared of pre-existing vegetation. Lowdensity plots had five plants per plot $\left(6400 \mathrm{~cm}^{2}\right)$, with four corner plants spaced $60-\mathrm{cm}$ apart and one plant in the center. High-density plots had 16 plants per plot $\left(6400 \mathrm{~cm}^{2}\right)$ in a $4 \times$ 4 square arrangement, with each plant being $20 \mathrm{~cm}$ from its nearest neighbor. Our low-density plots $\left(8\right.$ plants $\cdot \mathrm{m}^{-2}$ ) represented a density at which rangeland plants display optimal establishment (Whisenant 1999), while our highdensity plots $\left(25\right.$ plants $\left.\cdot \mathrm{m}^{-2}\right)$ represented a density intermediate between optimal establishment and typical seeding rates. A 40-cm aisle surrounded each plot on all sides, and a single-row border was maintained around the perimeter of the plot area $40 \mathrm{~cm}$ from the nearest plot edge.

A total of 288 plots across 12 populations of $P$. spicata, two plant densities, and two defoliation treatments were arranged in a split-split plot design with six replicated blocks. Defoliation treatment was the whole-plot factor, density was the split-plot factor, and population was the split-split-plot factor. All effects were considered fixed except replication and its interactions. During the establishment period, the plots were irrigated twice, after which the plants received no supplemental water.

On 8 May 2006 at the pre-anthesis stage (i.e., when the spike was fully exserted but prior to pollen shed), we applied the first defoliation to the whole plots designated for the "spring-defoliation" treatment, by clipping plants at a $10-\mathrm{cm}$ height. This is the phenological stage at which defoliation is most deleterious (Ganskopp 1988; Jones and Nielson 1997; Sheley et al. 1997). Biomass was oven-dried at $60^{\circ} \mathrm{C}$ for $72 \mathrm{~h}$, and dry weights were recorded. Stomatal conductance was measured on 5-6 June with a leaf porometer (Model SC-1, Decagon Devices, Pullman, WA). Measurements were taken near the center of each of five randomly selected mature green leaves of the center plant for low-density plots and on any of the four center plants of high-density plots. We harvested regrowth (biomass above defoliation height) of defoliated plots and reproductive biomass (with matured seeds) on the nonspring-defoliated (control) plots on 15 July. Fall regrowth was harvested for both defoliation treatments on 11 November.

On 31 May 2007, we spring-defoliated the same set of whole plots as in May 2006, again when plants were at the preanthesis stage. We measured stomatal conductance on 25-26 June 2007 using same procedure as in 2006. On 31 July, we harvested biomass of both spring-defoliated and control whole plots. No defoliation was applied for either treatment in fall 2007 because regrowth was minimal due to drought conditions 
Table 1. F-values of repeated-measures analysis of variance for shoot biomass, defoliation tolerance, and stomatal conductance for $12 P$. spicata populations $(P)$ in response to two defoliation (DF) treatments and two plant densities (DN).

\begin{tabular}{|c|c|c|c|c|}
\hline Effects & df & $\begin{array}{l}\text { Shoot biomass } \\
\left(\mathrm{g} \cdot \mathrm{m}^{-2}\right) \\
(2006-2008)\end{array}$ & $\begin{array}{c}\text { Defoliation } \\
\text { tolerance (\%) } \\
\text { (2006-2008) }\end{array}$ & $\begin{array}{c}\text { Stomatal conductance } \\
\left(\mathrm{mmol} \cdot \mathrm{m}^{-2} \cdot \mathrm{s}^{-1}\right) \\
(2006-2007)\end{array}$ \\
\hline DF & 1 & $61.34^{* *}$ & - & 31.20 ** \\
\hline DN & 1 & $20.42^{\star * *}$ & 0.03 & 22.71 ** \\
\hline $\mathrm{DF} \times \mathrm{DN}$ & 1 & 0.02 & - & 0.23 \\
\hline$P$ & 11 & $15.31^{* * *}$ & $2.51^{*}$ & 1.11 \\
\hline$P \times D F$ & 11 & $5.20 * \star \star$ & - & 0.81 \\
\hline $\mathrm{P} \times \mathrm{DN}$ & 11 & 1.15 & 1.07 & 0.54 \\
\hline $\mathrm{P} \times \mathrm{DF} \times \mathrm{DN}$ & 11 & 0.75 & - & 0.74 \\
\hline Year & 2 & $218.93^{* * *}$ & $77.92^{\star * *}$ & $106.69 * * *$ \\
\hline Year $\times$ DF & 2 & $78.06^{\star * *}$ & - & 0.38 \\
\hline Year $\times$ DN & 2 & $39.56^{\star \star \star}$ & 0.02 & 4.89 \\
\hline Year $\times D F \times D N$ & 2 & 0.06 & - & 2.70 \\
\hline Year $\times P$ & 22 & $2.55^{\star \star}$ & $1.60^{*}$ & 0.44 \\
\hline Year $\times \mathrm{P} \times \mathrm{DF}$ & 22 & 1.02 & - & 0.98 \\
\hline Year $\times \mathrm{P} \times \mathrm{DN}$ & 22 & 0.56 & 0.84 & 0.64 \\
\hline Year $\times \mathrm{P} \times \mathrm{DF} \times \mathrm{DN}$ & 22 & 0.34 & - & 0.75 \\
\hline
\end{tabular}

(287.8 mm annual rainfall in 2007 vs. $388.0 \mathrm{~mm}$ long-term average annual rainfall; Utah Climate Center 2012).

In the following year (2008), we harvested biomass from both spring-defoliated and control whole plots on $31 \mathrm{May}$, and for the last time, on 2 September 2008. In plots of three replications, we removed four soil cores $(10-\mathrm{cm}$ diameter $\times 17$ $\mathrm{cm}$ height, $\left.1335 \mathrm{~cm}^{3}\right)$ between plants with a golf-cup cutter $(\mathrm{H}$ 10 Hole cutter, KSAB Golf Equipment, Västerås, Sweden) from 9 to 13 September. Each core was approximately $15 \mathrm{~cm}$ from the center of the plot in each direction. We cleaned root samples with water, refrigerated them, and then cleaned them a second time before scanning with WinRHIZO Pro Version 2005b (Reagent Instrument Inc, Québec City, Canada). Roots were oven dried at $60^{\circ} \mathrm{C}$ for $48 \mathrm{~h}$ and weighed. Root-length density (root length per volume of soil), average root diameter, and specific root length (length per biomass) were calculated from these samples.

To summarize, for all defoliations, shoot biomass was removed at a $10-\mathrm{cm}$ height from all individuals within the plot. The spring-defoliation treatment received a single defoliation in spring at the early-reproductive boot phase. This was followed with a defoliation in mid-summer (2006 and 2007) and late fall (2006 only). In contrast, the control treatment received only the mid-summer and fall defoliations, when deleterious effects are minimal.

Shoot biomass, spring-defoliation tolerance, stomatal conductance, and root biomass data were analyzed using PROC MIXED and PROC REG in SAS 9.2 (SAS Institute 2008). Normality assumptions were not met for defoliated-to-control shoot-biomass ratio (defoliation tolerance) and root-length density, so data were normalized with a log transformation. A

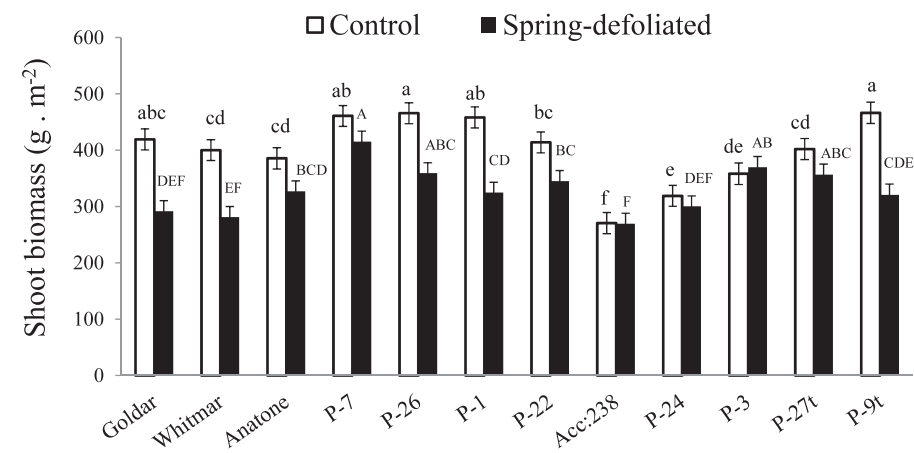

Figure 1. Means and standard errors of $12 P$. spicata populations for average annual shoot biomass (2006-2008) under nonspring-defoliated (control) and spring-defoliated treatments. Different letters represent significant $(P<0.05)$ differences among populations within control (lower case) and spring-defoliated (upper case) treatments.

repeated-measure ANOVA was performed on shoot biomass. When three-way and two-way interactions were not significant they were removed from the model. We separated least-squares means with an $\mathrm{LSD}_{0.05}$. Number of surviving plants was not independent of the density treatment, and hence it was not used as a covariate. Instead, we analyzed shoot biomass per plant for each density with PROC MIXED.

\section{RESULTS}

\section{Shoot Biomass}

For shoot biomass per area, effects of density, springdefoliation, and population interacted with year separately (Table 1), but no three-way interaction was significant. Springdefoliation increased production of shoot biomass per area $7 \%$ in $2006\left(307.0 \pm 10.6 \mathrm{~g} \cdot \mathrm{m}^{-2}\right.$ vs. $\left.328.3 \pm 10.7 \mathrm{~g} \cdot \mathrm{m}^{-2}\right)$, the first year of spring-defoliation. However, shoot biomass per area was subsequently reduced $35 \%$ in $2007\left(589.6 \pm 10.8 \mathrm{~g} \cdot \mathrm{m}^{-2}\right.$ vs. $\left.382.3 \pm 10.7 \mathrm{~g} \cdot \mathrm{m}^{-2}\right)$ and $14 \%$ in $2008 \quad(354.7 \pm 10.7$ $\mathrm{g} \cdot \mathrm{m}^{-2}$ vs. $\left.305.0 \pm 10.7 \mathrm{~g} \cdot \mathrm{m}^{-2}\right)$.

Totaled across the 3 yr (2006-2008), shoot biomass per area for the control treatment was $19 \%$ greater than for the springdefoliated treatment $\left(417.1 \pm 8.1 \mathrm{~g} \cdot \mathrm{m}^{-2}\right.$ vs. $338.5 \pm 8.1$ $\mathrm{g} \cdot \mathrm{m}^{-2}$; Table 1$)$. Populations varied significantly and interacted with spring-defoliation treatment for 3-yr shoot biomass per area, but we found no interaction with density (Table 1$)$. The P9t, P-26, P-7, and P-1 populations had the greatest shoot biomass per area for the control treatment, while P-24 and Acc:238 exhibited the least control shoot biomass (Fig. 1). Populations P-7 and P-3 had the greatest biomass per area when spring defoliated.

Totaled across the $3 \mathrm{yr}$ (2006-2008), shoot biomass per area at high density was $8 \%$ greater than at low density $(391.9 \pm 8.1$ vs. $366.9 \pm 8.1 \mathrm{~g} \cdot \mathrm{m}^{-2}$; Table 1$)$. Shoot biomass per area in 2006 was $40 \%$ greater at high density than at low density (235.7 vs. $168.5 \pm 5.8 \mathrm{~g} \cdot \mathrm{m}^{-2}$ ), while in 2007 and 2008 shoot biomass per area at the two densities was similar (Table 1). Average shoot biomass per plant was $55.0 \%, 70.9 \%$, and $66.6 \%$ lower at high density than at low density in 2006, 2007, 


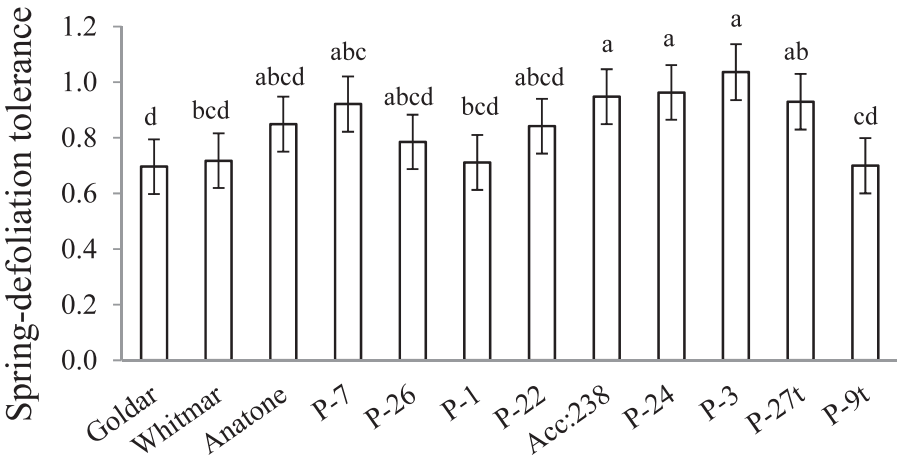

Figure 2. Means and standard errors for spring-defoliation tolerance of 12 P. spicata populations across two densities calculated from 3-yr (2006$2008)$ total biomass production. Different letters represent significant $(P<0.05)$ differences among populations.

and 2008 , respectively (33.8 vs. $15.2 \pm 1.1$ g; 62.3 vs. $18.3 \pm 1.1$ g; 41.2 vs. $13.7 \pm 1.1$ g; Fig. S1; Table S2; available online at http://dx.doi.org/10.2111/REM-D-13-00049.s1). Populations did not interact with densities for shoot biomass per area (Table 1$)$.

(a)

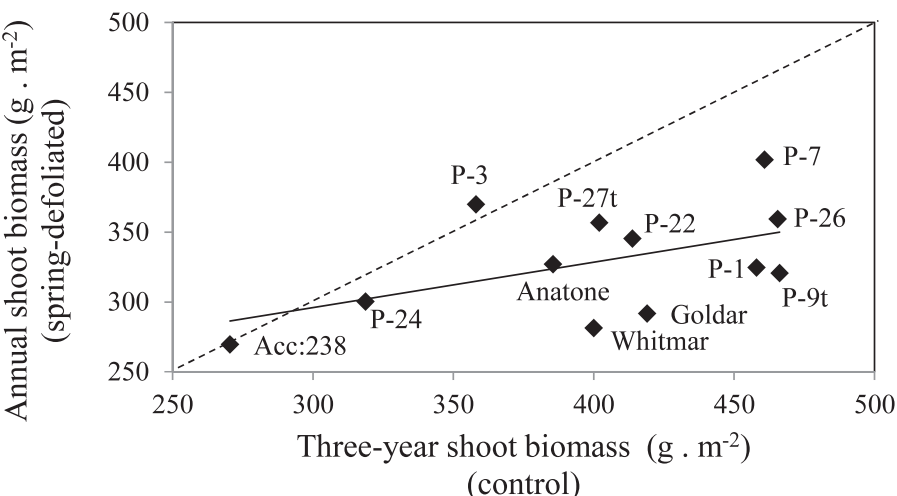

(b)

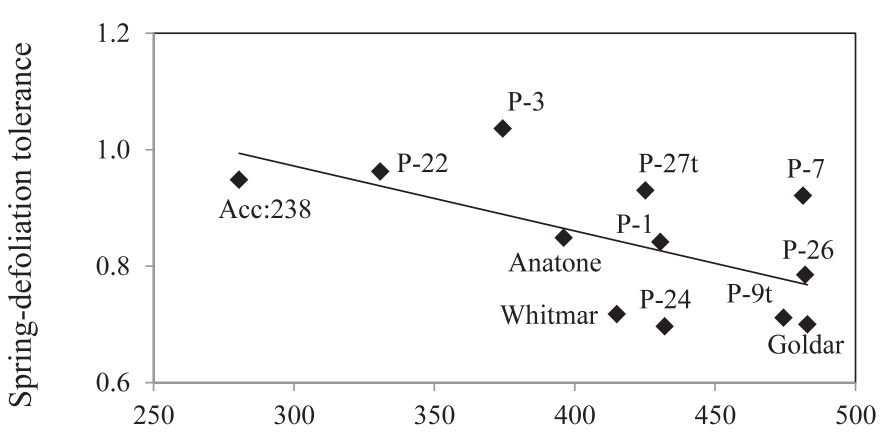

Three-year shoot biomass $\left(\mathrm{g} \cdot \mathrm{m}^{-2}\right)$ (control)

Figure 3. Linear regression of (a) 3-yr (2006-2008) spring-defoliated shoot biomass on control shoot biomass, with the dashed line (--.-) showing the line of compensation, (b) spring-defoliation tolerance on 3-yr (2006-2008) control shoot biomass.
Table 2. F-values for analysis of variance of morphological traits of $12 P$. spicata populations $(\mathrm{P})$ in response to two root defoliation (DF) treatments and two plant densities (DN).

\begin{tabular}{lrcccc}
\hline \multicolumn{1}{c}{ Traits } & df & $\begin{array}{c}\text { Root } \\
\text { biomass } \\
\left(\mathrm{g} \cdot \mathrm{m}^{-2}\right)\end{array}$ & $\begin{array}{c}\text { Root } \\
\text { diameter } \\
(\mathrm{mm})\end{array}$ & $\begin{array}{c}\text { Root } \\
\text { length density } \\
\left(\mathrm{mm} \cdot \mathrm{cm}^{-3}\right)\end{array}$ & $\begin{array}{c}\text { Specific } \\
\text { root length } \\
\left(\mathrm{mm} \cdot \mathrm{g}^{-1}\right)\end{array}$ \\
\hline DF & 1 & 6.41 & 2.22 & 5.54 & 0.20 \\
DN & 1 & $49.22^{\star *}$ & $11.33^{\star *}$ & 3.91 & 3.51 \\
$\mathrm{DF} \times \mathrm{DN}$ & 1 & $27.40^{\star * *}$ & 0.27 & $13.52^{\star}$ & 0.19 \\
$\mathrm{P}$ & 11 & $3.16^{\star *}$ & 1.22 & $2.76^{\star *}$ & 1.37 \\
$\mathrm{DF} \times \mathrm{P}$ & 11 & 1.19 & 0.63 & 1.16 & 0.83 \\
$\mathrm{DN} \times \mathrm{P}$ & 11 & $2.17^{*}$ & 1.45 & 0.93 & 0.66 \\
$\mathrm{DN} \times \mathrm{DF} \times \mathrm{P}$ & 11 & 0.74 & 0.80 & 0.87 & 0.65 \\
\hline $\mathrm{P}<0.05$ & & & & &
\end{tabular}

${ }^{\star} P<0.05$.

$\star * P<0.01$.

$* * * P<0.0001$

\section{Spring-defoliation Tolerance}

Spring-defoliation tolerance was not affected by density, but populations differed $(P<0.05)$ for this trait (Table 1$)$. Springdefoliation tolerance of the P-3 population was higher $(P<0.05)$ than for Whitmar, Goldar, P-26, P-1, and P-9t (Fig. 2). On average, spring-defoliation tolerance differed among years, and populations interacted with year for this variable. This interaction was caused by greater reductions in spring-defoliation tolerance for the P-24, P-1, P-22, and P-27t populations from 2006 to later years than was the case for the remaining populations. Regression of spring-defoliated biomass on control biomass was only marginally positive $\left(R^{2}=0.26 ; P<0.10\right.$; Fig. $\left.3 a\right)$, while regression of springdefoliation tolerance on control shoot biomass was negative $\left(R^{2}=0.36 ; P<0.05\right.$; Fig. 3b).

\section{Root Traits}

Root biomass per area was $52.3 \%$ lower at low density than at high density $\left(2.8 \pm 0.4\right.$ vs. $5.8 \pm 0.4 \mathrm{~g} \cdot \mathrm{m}^{-2}$; Table 2$)$. Springdefoliation and density interacted for root biomass; at high density, spring-defoliation reduced root biomass per area by $30.9 \%\left(6.9 \pm 0.8\right.$ vs. $\left.4.7 \pm 0.4 \mathrm{~g} \cdot \mathrm{m}^{-2}\right)$, while at low density root biomass per area was not affected by spring-defoliation $\left(2.5 \pm 0.4\right.$ vs. $\left.3.0 \pm 0.4 \mathrm{~g} \cdot \mathrm{m}^{-2}\right)$. Populations varied for root biomass per area and interacted with density but did not interact with spring-defoliation (Table 2). At high density, P-1, P-22, P-26, Whitmar, P-3, and Anatone produced the greatest root biomass per area, while P-9t and Acc:238 produced the least. At low density, P-7, P-26, Whitmar, and Anatone produced the greatest root biomass per area, while Acc:238 produced the least (Fig. 4). At high density, we found a positive relationship $\left(R^{2}=0.39 ; P<0.05\right.$; Fig. 5a) between reductions in shoot and root biomass across populations following springdefoliation. However, no relationship $(P>0.05)$ was found at low density (Fig. 5b). In addition, there was a negative association among populations $\left(R^{2}=0.34 ; P<0.05\right)$ between reduction in root biomass from spring-defoliation (averaged across densities) and spring-defoliation tolerance (averaged across densities; Fig. 5c). 


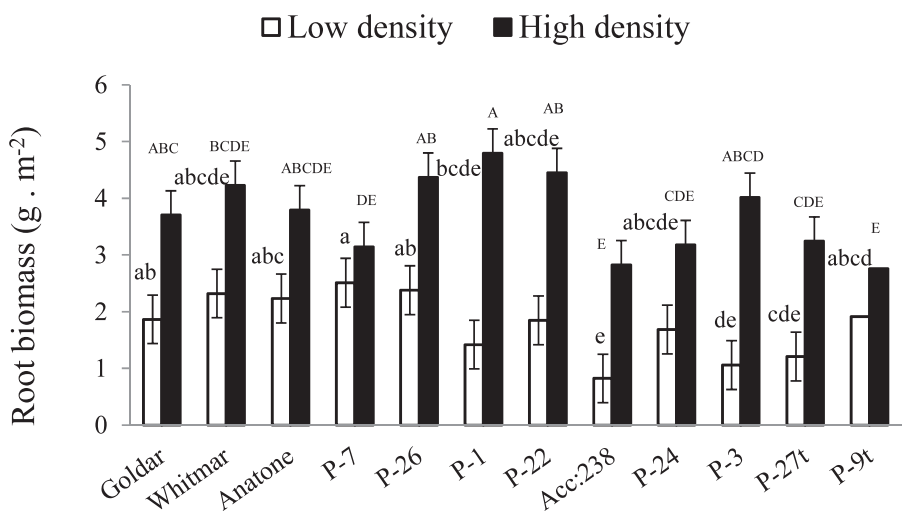

Figure 4. Means and standard errors of 2008 root biomass for $12 P$. spicata populations at high and low densities. Different letters represent significant $(P<0.05)$ differences among populations at low-density (lower case) and high-density (upper case).

Root diameter did not differ with spring-defoliation treatment, but high density displayed $4.1 \%$ greater root diameter than low density $(4.52 \pm 0.05$ vs. $4.34 \pm 0.05 \mathrm{~mm})$. Rootlength density was $58.0 \%$ greater at high density compared with low density $\left(0.079 \pm 0.005\right.$ vs. $\left.0.050 \pm 0.005 \mathrm{~m} \cdot \mathrm{cm}^{-3}\right)$ for the control treatment, while spring-defoliation resulted in similar root length densities for the two density treatments. Populations differed for root-length density, but they did not interact with either density or spring-defoliation. P-26, P-1, P7, Whitmar, Goldar, P-27t, and P-22 produced high root-length density, while P-9t and P-24 produced the least. Specific root length was similar among spring-defoliation treatments, densities, and populations (Table 2).

\section{Stomatal Conductance}

Stomatal conductance was significantly affected by density, spring-defoliation, and year, but none of these factors interacted with one another (Table 1). Conductance was $26.3 \%$ greater for low density $\left(122.6 \pm 8.6\right.$ vs. $\left.97.1 \pm 8.6 \mathrm{mmol} \cdot \mathrm{m}^{-2} \cdot \mathrm{s}^{-1}\right)$ and $100.9 \%$ greater for the spring-defoliation treatment $\left(150.6 \pm 11.2\right.$ vs. $\left.74.9 \pm 11.6 \mathrm{mmol} \cdot \mathrm{m}^{-2} \cdot \mathrm{s}^{-1}\right)$. The 12 P. spicata populations neither varied for stomatal conductance nor interacted with any of the above factors for this trait (Table 1).

\section{DISCUSSION}

Previous studies have demonstrated that defoliation is detrimental to P. spicata during elongation of reproductive tillers in the spring, which is the season of greatest productivity for semiarid rangelands (Sims and Singh 1978), both for immature (Brewer et al. 2007) and mature plants (Richards and Caldwell 1985; Ganskopp 1988). Consistent with previous studies (Cook and Stoddard 1963; Ganskopp 1988; Sheley et al. 1997), we found that spring-defoliation negatively impacted plant performance and that P. spicata populations displayed differential responses to spring-defoliation.

Belsky (1986) asserted that species of arid and semiarid grasslands generally undercompensate upon defoliation. Although defoliation increased shoot biomass in the first year when plants were still establishing, two consecutive years of
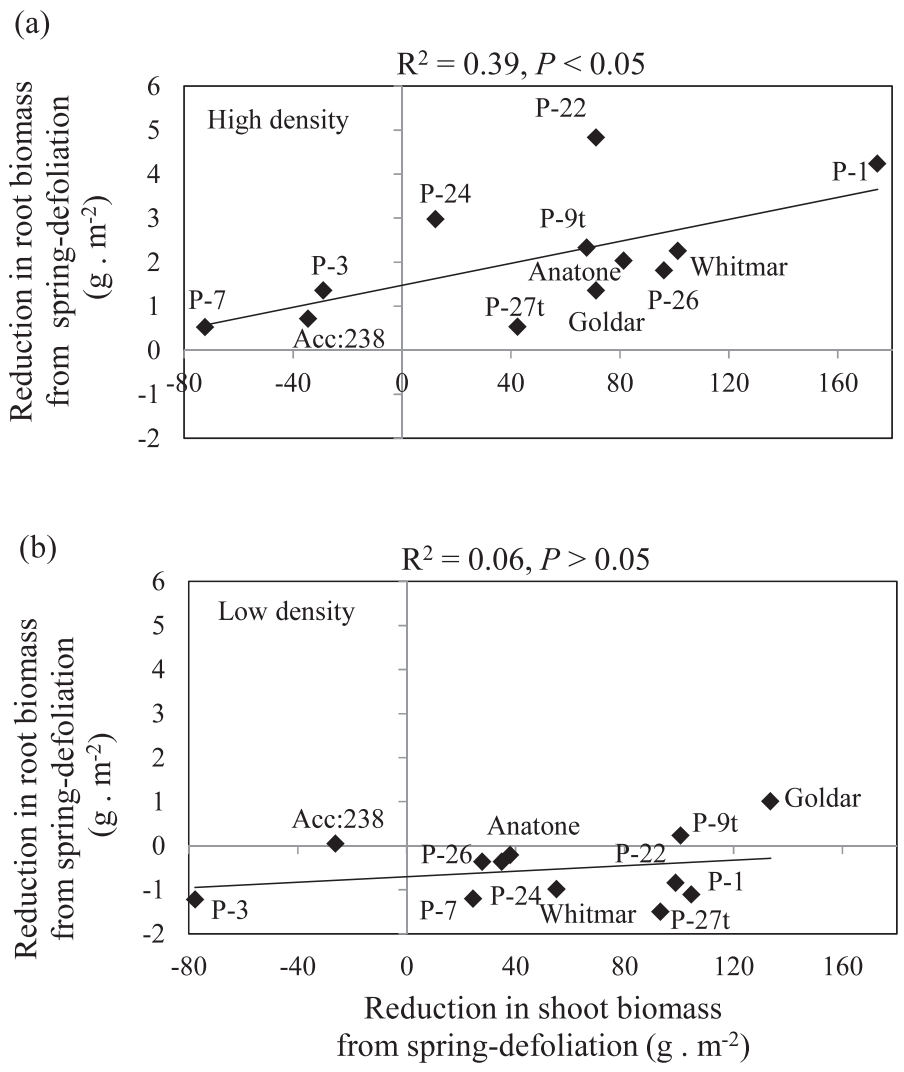

(c)

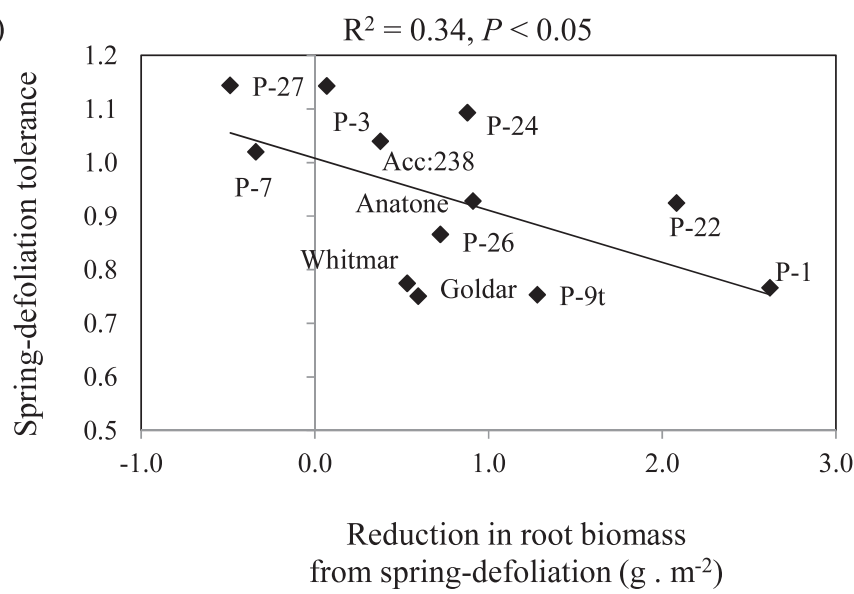

Figure 5. Linear regression of reduction in 2008 root biomass on reduction in 2008 shoot biomass after spring-defoliation at (a) high and (b) low density and (c) linear regression of spring-defoliation tolerance based on 3yr (2006-2008) shoot biomass on reduction in 2008 root biomass by spring-defoliation.

spring-defoliation on more mature plants had a pronounced negative effect on shoot biomass production. Therefore, we rejected the null hypothesis that $P$. spicata populations would compensate for defoliation, except for P-3 and A:238. Thus, our results mostly agree with Belsky's (1986) assertion of undercompensation.

Our second null hypothesis was that more recently released plant materials (Anatone and P-7) would be no more productive for the undefoliated control treatment than the older released materials (Whitmar and Goldar). We failed to 
reject the null hypothesis for Anatone but rejected it for P-7, leading to the conclusion that this newer plant material was improved for above-ground biomass production. In addition, P-7 displayed the greatest spring-defoliation tolerance of the four commercial plant materials, with no differences seen among the remaining three.

Our third hypothesis was that less-productive populations would be no better able to compensate for lost biomass and therefore be no more spring-defoliation tolerant at both densities. Because there was no significant population $\times$ density interaction for spring-defoliation tolerance, populations can be compared for means across densities. The three least productive populations (Acc:238, P-24, and P-3) did display the highest compensation and highest spring-defoliation tolerance, and we also noted a negative correlation between control shoot biomass and spring-defoliation tolerance across populations. These findings provide support to reject this null hypothesis.

The positive relationship between control shoot biomass and spring-defoliated shoot biomass, combined with the negative relationship between control shoot biomass and spring-defoliation tolerance, indicates that control biomass increased as spring-defoliated biomass increased, but at a lower rate. This suggests a cost related to spring-defoliation tolerance across P. spicata populations (Grime 2001; Rotundo and Aguiar 2008). Arid environments are often thought to confer resistance to grazing (Coughenour 1985; Milchunas et al. 1988; Adler et al. 2004). Hence, the high spring-defoliation tolerances of the two least-productive populations, Acc:238 and P-24, which was derived from Acc:238, may have been conditioned by the arid climate of the Acc: 238 collection site in eastern Washington $(250 \mathrm{~mm}$ average annual precipitation).

Due to negative density-dependence, shoot biomass per plant was more negatively impacted at high density than at low density in all 3 yr (Yoda et al. 1963; Westoby 1984; Silvertown 1987). Negative density-dependence was further evidenced by a significant year $\times$ density interaction for shoot biomass, whereas a significantly higher biomass at high density relative to low density diminished from 2006 to the following years as the plants became established. Similarly, variables like root biomass, root diameter, and root-length density were more negatively impacted by defoliation at high density than at low density. Therefore, at high rangeland seeding densities, both above-ground and below-ground productivity of $P$. spicata may be negatively impacted by spring-defoliation. This density-dependent effect was similar across populations.

If the fourth null hypothesis, namely that curtailing root growth is unrelated to spring-defoliation tolerance, is tenable, no significant slope should result when spring-defoliation tolerance is regressed on reductions in root biomass of individual populations due to spring-defoliation. In fact, however, we found a negative slope for this regression, suggesting that root biomass is most greatly reduced in populations that display a lack of tolerance to springdefoliation aboveground. Relative to the grazing-tolerant, exotic perennial bunchgrass, Agropyron desertorum, $P$. spicata is reported to exhibit unabated root growth following spring-defoliation (Caldwell et al. 1981; Richards 1984).
Differential population response for shoot biomass was primarily due to defoliation rather than density, while the reverse was true for root biomass. The dominant effect of spring-defoliation on shoot biomass may be intuitive, as defoliation directly alleviates above-ground competition. However, this finding is inconsistent with previous studies (Caldwell et el. 1981; McNaughton et al. 1998).

Intraspecific variation in traits is a consequence of genetic differences and phenotypic plasticity, which also has a genetic basis (Albert et al. 2011; Burns and Strauss 2012). Plasticity is regarded as an adaptive response to competition (Burns and Strauss 2012). In this study, we saw considerable reductions in shoot and root biomass in response to spring-defoliation, suggesting that populations are relatively plastic for these traits. Specifically, we found that root biomass was greatly reduced after defoliation at high density, though not at low density.

Stomatal conductance was reduced by competition above ground (control treatment) and below ground (high-density treatment). Spring-defoliation and high density were negatively synergistic in 2006, as defoliation increased stomatal conductance more at low density $(40 \%)$ than at high density $(4 \%)$. This suggests greater increments of photosynthetic activity at lower levels of competition. These results are compatible with those of Brewer et al. (2007), who showed that defoliation promoted photosynthetic activity of $P$. spicata. Gibson and Skeel (1996) also reported that stomatal conductance decreased with increasing neighbor density in a greenhouse. Spring-defoliation and density again affected stomatal conductance in 2007, and as 2007 was a drought year (Miskus 2007), it could have been that photosynthetic activity did not significantly increase after spring-defoliation, as this stress was compounded by limited soil water.

In our study, spring-defoliation tolerance on a per-area basis did not differ between densities, and density did not interact with either populations or years. This trend was repeated for spring-defoliation tolerance on a per-plant basis (Fig. S2; available online at http://dx.doi.org/10.2111/ REM-D-13-00049.s1). While spring-defoliation tolerance is generally considered to be greater in the absence of plant competition (Lee and Bazzaz 1980; Archer and Detling 1984; Banyikwa 1988), in our case any differences in resource availability due to density were insufficient to generate differences in spring-defoliation tolerance. While density had no discernible effect on production of above-ground biomass per area or spring-defoliation tolerance, it had a large impact on root biomass. This could be partly explained by the differences in planting pattern of the two density treatments relative to the position of the holes dug to harvest root samples. Nevertheless, density interacted with defoliation and P. spicata populations for root biomass. These results suggest that density had a greater impact on resource availability to roots than to shoots, presumably because the soil-water resource was shared among plants.

\section{IMPLICATIONS}

We report intraspecific variation for spring-defoliation tolerance that is presumably under genetic control. We agree with 
Del-Val and Crawley (2005) that moderate defoliation under experimental conditions cannot be extrapolated to responses of recurrent herbivory in the field. Nevertheless, this study demonstrates that the populations of P. spicata currently in use for restoration applications are sensitive to even the moderate defoliation treatment that we applied.

Spring-defoliation tolerance, when calculated on a percentage basis relative to the nonspring defoliated control, was negatively associated with productivity of the control for both densities, indicating a possible trade-off. This might lead one to an interpretation that selection of plant materials for increased control shoot biomass would result in reduced defoliation tolerance, particularly if larger plants are preferentially grazed. This issue highlights the importance of grazing deferment until after the time of grazing susceptibility has passed. However, we note several potential exceptions to this negative relationship as deviations from the regression line, emphasizing the importance of direct evaluation of plant materials for defoliation tolerance. As an example, artificial selection of P-24 from Acc:238 increased control shoot biomass without reducing spring-defoliation tolerance, and artificial selection of P-22 from P-1 resulted in lower defoliation-induced reductions in shoot and root biomass at high density. On the other hand, artificial selection of P-26 from P-7 increased root biomass at high density but reduced shoot biomass under spring-defoliation, which may be related to a concomitant loss of rhizomes.

\section{ACKNOWLEDGMENTS}

We thank Peter B. Adler, Ron J. Ryel, and Chris C. Call for their helpful advice and comments. We thank Dale Nielson, Justin Williams, Brian Bell, Eamonn Leonard, Breanne Davis, Devin Vincent, Tren Hagman, and Jenny Christiansen for assistance in the field. We also thank Susan Durham for her assistance in statistical analysis. Helpful comments and assistance in the field by Shomen Mukherjee and helpful suggestions on statistical analysis by Sumanta Bagchi are thankfully acknowledged. We thank John R. Hendrickson and Jack E. Staub for their valuable comments.

\section{LITERATURE CITED}

Adler, P. B., D. G. Mllchunas, W. K. Lauenroth, O. E. Sala, and I. C. Burke. 2004. Functional traits of graminoids in semi-arid steppes: a test of grazing histories. Journal of Applied Ecology 41:653-663.

Adler, P. B., D. G. Mllchunas, O. E. Sala, I. C. Burke, and W. K. Lauenroth. 2005. Plant traits and ecosystem grazing effects: comparison of U.S. sagebrush steppe and Patagonian steppe. Ecological Applications 15:774-792.

Albert, C. H., F. Grassein, F. M. Schurr, G. Vieilledent, and C. Violle. 2011. Why and how should intra-specific variability be considered in trait-based plant ecology? Perspectives in Plant Ecology, Evolution and Systematics 13:217-225.

Archer, S., And J. K. Detulng. 1984. The effect of defoliation and competition on the growth of tillers of two North American mixed-grass prairie graminoids. Oikos 43:351-357.

BanYIKWA, F. F. 1988. The growth response of two East African perennial grasses to defoliation, nitrogen fertilizer, and competition. Oikos 51:25-30.

Belsky, A. J. 1986. Does herbivory benefit plants? A review of the evidence. The American Naturalist 127:870-892.

Brewer, T. K., J. C. Mosley, D. E. Lucas, and L. R. Schmidt. 2007. Bluebunch wheatgrass response to spring defoliation on foothill rangeland. Rangeland Ecology \& Management 60:498-507.
Burns, J. H., and S. Y. Strauss. 2012. Effects of competition on phylogenetic signal and phenotypic plasticity in plant functional traits. Ecology 93:S126-S137.

Busso, C. A., D. D. Briske, and V. Olalde-Portugal. 2001. Root traits associated with nutrient exploitation following defoliation in three coexisting perennial grasses in a semi-arid savanna. Oikos 93:332-342.

Caldwell, M. M., J. H. Richards, D. A. Johnson, R. S. Nowak, and R. S. Dzurec. 1981. Coping with herbivory: photosynthetic capacity and resource allocation in two semi-arid Agropyron bunchgrasses. Oecologia 50:14-24.

Chapin, F. S. 1980. The mineral nutrition of wild plants. Annual Review of Ecology and Systematics 11:233-260.

Cook, C. W., and L. A. Stoddart. 1963. The effect of intensity and season of use on the vigor of desert range plants. Journal of Range Management 16:315-317.

Coughenour, M. B. 1985. Graminoid responses to grazing by large herbivores: adaptations, exaptations, and interacting processes. Annals of the Missouri Botanical Garden 72:852-863.

Del-Val, E., and M. J. Crawley. 2005. What limits herb biomass in grasslands: competition or herbivory? Oecologia 142:202-211.

GansKopP, D. 1988. Defoliation of Thurber needlegrass: herbage and root responses. Journal of Range Management 41:472-476.

GiBSON, D. J., AND V. A. SkeEL. 1996. Effects of competition on photosynthetic rate and stomatal conductance of Sorghastrum nutans. Photosynthetica 32:503-512.

GRIME, J. P. 2001. Plant strategies, vegetation processes, and ecosystem properties. New York, NY, USA: John Wiley \& Sons. 460 p.

Jones, T. A., AND D. C. Nielson. 1997. Defoliation tolerance of bluebunch and Snake River wheatgrasses. Agronomy Journal 89:270-275.

LeE, T. D., And F. A. Bazzaz. 1980. Effects of defoliation and competition on growth and reproduction in the annual plant Abutilon theophrasti. Journal of Ecology 68:813821.

Loreti, J., M. Osterheld, and S. Osvaldo. 2001. Lack of intraspecific variation in resistance to defoliation in a grass that evolved under light grazing pressure. Plant Ecology 157:195-202.

Mack, R. N., And J. N. Thompson. 1982. Evolution in steppe with few large, hooved mammals. American Naturalist 119:757-773.

McNaughton, S. J. 1983. Compensatory plant growth as a response to herbivory. Oikos 40:329-336

McNaughton, S. J., F. F. Banyikwa, and M. M. McNaughton. 1998. Root biomass and productivity in a grazing ecosystem. Ecology 79:587-592.

Milchunas, D. G., O. E. Sala, and W. K. Lauenroth. 1988. A generalized model of the effects of grazing by large herbivores on grassland community structure. American Naturalist 132:87-106.

Miskus, D. 2007. US drought monitor: September 25, 2007. Available at: http://www. ncdc.noaa.gov/img/climate/research/2007/sep/usdm-070925.gif. Accessed 15 October 2012.

Monsen, S. B., R. Stevens, And N. L. Shaw. 2004. Restoring western ranges and wildlands. U.S. Forest Service General Technical Report RMRS-GTR 136 (Vol. 2). Fort Collins, CO, USA: US Forest Service.

MueggleR, W. F. 1972. Influence of competition on the responses of bluebunch wheatgrass to clipping. Journal of Range Management 25:88-92.

MueggleR, W. F. 1975. Rate and pattern of vigor recovery in Idaho fescue and bluebunch wheatgrass. Journal of Range Management 28:198-204.

RichaRDS, J. H. 1984. Root growth response to defoliation in two Agropyron bunchgrasses: field observations with an improved root periscope. Oecologia 64:21-25.

Richards, J. H., and M. M. Caldwell. 1985. Soluble carbohydrates, concurrent photosynthesis and efficiency in regrowth following defoliation: a field study with Agropyron species. Journal of Applied Ecology 22:904-920.

Rotundo, J. L., AND M. R. Aguiar. 2008. Herbivory resistance traits in populations of Poa ligularis subjected to historically different sheep grazing pressure in Patagonia. Plant Ecology 194:121-133.

SAS InStITUTE. 2008. SAS/STAT 9.2 user's guide. Cary, NC, USA: SAS Institute Inc.

ShelEY, R. L. 2008. Crested wheatgrass defoliation intensity and season on medusahead invasion. Rangeland Ecology \& Management 61:211-217.

Sheley, R. L., B. E. Olson, And L. L. LaRSon. 1997. Effect of weed seed rate and grass defoliation level on diffuse knapweed. Journal of Range Management 50:39-43.

SiLverTOWN, J. 1987. Introduction to plant population ecology. New York, NY, USA: John Wiley \& Sons. $229 p$ 
Sims, P. L., And J. S. Singh. 1978. The structure and function of ten western North American grasslands. Journal of Ecology 66:573-597.

Trlica, M. J., and L. R. Rittenhouse. 1993. Grazing and plant performance. Ecological Applications 3:21-23.

Utah Climate Center. 2012. Utah State University Climate Center. Available at: http:// climate.usurf.usu.edu/mapGUI/mapGUI.php. Accessed 10 October 2012.
Westoby, M. 1984. The self-thinning rule. Advances in Ecological Research 51:2530.

WhISENANT, S. G. 1999. Repairing damaged wildlands: a process-oriented, landscapescale approach. Cambridge, UK: Cambridge University Press. 312 p.

Yoda, K., T. KIRA, H. Ogawa, and K. HozUmı. 1963. Intraspecific competition among higher plants. XI. Self-thinning in over-crowded pure stands under cultivated and natural conditions. Journal of Biology of Osaka City University 51:25-30. 